\title{
Between Franks and Butler: British intelligence lessons from the Gulf War
}

\section{ABSTRACT}

Lessons for the intelligence community were publicly identified in a 1983 report by Lord Franks and 2004 report by Lord Butler. However, little is known of the lessons learned during the twenty years between the two. This article draws upon two newly released, previously classified, documents which examine British intelligence lessons from the 1990-1991 Gulf War. It provides a previously untold account of the crisis, exclusively from a British intelligence perspective, and presents new evidence that intersects across many intelligence debates. This article also challenges whether identified lessons remained learned and begins to question the wider learning process within the intelligence community.

'History is a mirror to the past and a lesson to the future.'

Since its formalisation, the British intelligence community has experienced very few investigations resulting in a public report. The first, in 1983, was pioneered by Lord Franks whilst chairing a review into the Falklands conflict. ${ }^{2}$ As part of a wider review the Franks committee provided an account of events leading up to the war, including intelligence reporting. They also considered whether the intelligence community should have foreseen the

\footnotetext{
${ }^{1}$ Henry Kissinger cited in Air Chief Marshal Sir David Parry-Evans, Report by the Granby Coordinator: Lessons Learned from the Gulf War, released upon a request under the Freedom Of Information Act made by the author. The file is later to be released to The National Archives, Kew under DEFE 11/945, 1991.

${ }^{2}$ Lord Oliver Franks, Falkland Islands Review (London: HMSO 1983).
} 
Argentinean invasion and, although concluding that the intelligence community could not be blamed for the lack of warning, recommended a number of lessons to be learned.

Twenty one years passed before the intelligence community was again held subject to similar public scrutiny. In 2004 Lord Butler chaired a committee to investigate and report upon the subject and use of intelligence on weapons of mass destruction (WMD) in the lead up to the 2003 Iraq War. ${ }^{3}$ As part of the terms of reference Lord Butler also identified a number of lessons to be implemented in the future gathering, evaluation and use of intelligence on WMD. ${ }^{4}$

Much has been written on the lessons learned from the Frank's report with some literature focused upon the impact upon the intelligence community, especially issues of warning and the role and structure of the JIC. ${ }^{5}$ Even more academic debate emerged from the lessons learned from the Butler report, along with assessments of the inquiry process itself. ${ }^{6}$ However, little is known of the intelligence lessons which were identified between 1983 and 2004 and which were only recognised internally, recorded in secret reports and disseminated

\footnotetext{
${ }^{3}$ Lord Robin Butler, Review of Intelligence on Weapons of Mass Destruction, HC 898 (London: HMSO 2004).

${ }^{4}$ Ibid., p.1.

${ }^{5}$ See for example Gerald W Hopple 'Intelligence and Warning: Implications and Lessons of the Falkland Islands War', World Politics, 36/3 April (1984) pp.339-361 and Philip H. J. Davies 'Organizational politics and the development of Britain's intelligence producer/consumer interface', Intelligence and National Security, 10/4 (1995) pp.113-132

${ }^{6}$ On lessons from Butler see for example Michael Herman 'Intelligence and the Iraqi Threat: British Joint Intelligence After Butler', The RUSI Journal, 149/4 (2004) pp.18-24 and Simon Case and Catherine Haddon 'Something Old, Something New: A Historical Perspective on the Butler Review', The Political Quarterly, 75/4 October (2004), pp.417-421. On the inquiry process see for example Alex Danchev 'The Reckoning: Official Inquiries and the Iraq War', Intelligence and National Security, 16/9 (2004) pp.436-466, Mark Phythian 'Flawed intelligence, limited oversight: official inquiries into prewar UK intelligence on Iraq' in James P. Pfiffner and Mark Phythian (eds.) Intelligence and National Security Policymaking on Iraq, (Manchester: Manchester University Press 2008) pp.191-210 and Robert Jervis 'Reports, Politics and Intelligence Failures: The Case of Iraq', Journal of Strategic Studies, 29/1 pp.3-52.
} 
to a limited distribution list. Two such previously classified documents have recently been released, as a result of requests made to the Ministry of Defence (MoD) under the Freedom of Information (FOI) Act. Each report examines and reveals lessons which were identified from the intelligence community's experience during the first Gulf War (1990-1991). ${ }^{7}$ As a result, the documents provide the opportunity for a closer assessment of the intelligence learning process between Franks and Butler to determine whether identified lessons were being learned. They also offer a unique glimpse into the secretive world of intelligence during an intervention which presently remains outside the archive release dates.

The first document to be released was a report produced by Air Chief Marshal Sir David Parry-Evans. Appointed as 'Granby Coordinator', Parry-Evans was responsible for overseeing all of the tasks that were required to be completed in the aftermath of the Gulf War. ${ }^{\mathrm{i}}$ The primary aim of his report is identified on the second page; 'to identify lessons for the future from Operation Granby' and the key lessons are summarised at the end of the 113 page document. At the time, this report was classified as 'secret'. When the House of Commons Defence Committee (HCDC) held an inquiry into the implementation of lessons learned from 'Granby' it requested a copy of the report but was refused. ${ }^{8}$ The document also includes an annex which features a copy of the publicly published despatch from the Joint Commander of Operation 'Granby' Air Chief Marshal Sir Patrick Hine, ${ }^{9}$ the classified overview reports from Hine and British Forces Commander Middle East General Peter de la

\footnotetext{
${ }^{7}$ Parry-Evans, Report by the Granby Coordinator; DIS, Intelligence Support to Operation Granby, released upon a request under the FOI Act, 1991.

${ }^{8} \mathrm{HCDC}$, Implementation of Lessons Learned from Operation Granby, HC43 (London: HMSO 1994) p.vi.

${ }^{9}$ Air Chief Marshal Sir Patrick Hine 'Despatch by Air Chief Marshal Sir Patrick Hine GCB ADC FRAES CBIM RAF Joint Commander of Operation Granby', The London Gazette, Second Supplement, 28 June 1991.
} 
Billière and a list of additional major studies which had been completed on Operation 'Granby', including overall planning and execution and equipment effectiveness studies.

The second document released under the FOI request was a listed major study entitled Intelligence Support to Operation Granby. The work was commissioned by the Chief of Defence Intelligence (CDI) on lessons to be learned from the operation for the Defence Intelligence Staff (DIS) and the annex list in the Parry-Evans report confirmed its prompt completion. The DIS report focuses upon reviewing the central intelligence support to 'Granby' and identifies 22 key lessons for the future. The author of the report is unknown but a cross-reference with the work by Parry-Evans confirms its authenticity and suggests it had been widely drawn upon by the Granby Coordinator.

This article endeavours to achieve two objectives. Firstly it will utilise the new sources to provide an account of the involvement of the British intelligence community in the Gulf War. As a result, it will provide a new perspective on the current Gulf War literature and contribute to the limited analysis from an exclusively British standpoint. ${ }^{10}$ It will be structured chronologically to provide an examination of intelligence within three different phases of the crisis; prior to the invasion of Kuwait, where intelligence was focused upon monitoring, warning and strategic intelligence; post invasion but prior to hostilities, when intelligence was focused upon operational planning but limited by the laws of peacetime; and during hostilities, whereby tactical intelligence became paramount. As a result, this article seek to

\footnotetext{
${ }^{10}$ For an authoritative account of the Gulf War see Lawrence Freedman and Efraim Karsh The Gulf Conflict: Diplomacy and War in the New World Order (London: Faber and Faber 1993). For various perspectives, including the British perspective, see Alex Danchev and Dan Keohane (eds.) International Perspectives on the Gulf Conflict, 1990-91 (Basingstoke: Macmillan 1994).
} 
contribute to the emerging literature on lesson learning in intelligence ${ }^{11}$ and will expose new evidence that spans across a number of concepts within intelligence literature; issues of warning, mirror-imaging, interrogation, intentions versus capabilities and intelligence liaison are all examined. ${ }^{12}$ Although these concepts and their surrounding academic debates will not be considered at length, empirical evidence will be presented which may be used for future analysis and debate contribution.

Secondly, this article will consider the process of intelligence lesson learning during this time and challenge whether lessons were learned. Lessons that were identified during the Gulf War will be discussed and investigation made into whether lessons were, and remained, implemented. Primacy will be placed upon the lessons formally identified within the two newly released documents and consequently the analysis will be principally, but not exclusively, focused upon defence intelligence. ${ }^{\text {ii }}$

PRIOR TO INVASION: 1 JANUARY 1990 - 1 AUGUST 1990

At the beginning of 1990 it had become clear to the intelligence community that the President of Iraq, Saddam Hussein, was moving away from relations with moderate Arab governments.

\footnotetext{
${ }^{11}$ See for example Len Scott \& R. Gerald Hughes 'Intelligence, crises and security: Lessons from history?', Intelligence and National Security, 21/5 (2006) pp.653-674, John N.L. Morrison 'British Intelligence Failures in Iraq', Intelligence and National Security, 26/4 (2011) pp.509-520 and Robert Dover and Michael S Goodman (eds.) Learning from the Secret Past (Washington: Georgetown University Press).

${ }^{12}$ See for example on warning Richard K. Betts 'Surprise Despite Warning: Why Sudden Attacks Succeed', Political Science Quarterly, 95/4 Winter (1980) pp.551-572; on mirrorimaging Les Aspin, 'Misreading Intelligence', Foreign Policy, 43 Summer (1981) pp.166172; on interrogation Huw Bennett, 'The Baha Mousa Tragedy: British Army Detention and Interrogation from Iraq to Afghanistan', The British Journal of Politics and International Relations (2012) pp.1-19; on intentions versus capabilities Raymond L. Garthoff 'On Estimating and Imputing Intentions', International Security, 2/3 (1978) pp.22-32; on liaison S. Lander, 'International Intelligence Co-operation: An Inside Perspective', Cambridge Review of International Studies, 2004, 17/3 October (2004) pp.481-93.
} 
Iraq was suffering from severe financial difficulties due to the bitter Iran-Iraq war (19801988). ${ }^{13}$ Following the end of the war, foreign debt servicing swallowed seven-eighths of Iraq's oil export income. ${ }^{14}$ Taking account of these factors the Joint Intelligence Committee (JIC) studied the procurement network of Iraq with great interest and concluded that the country had become 'a potential predatory power, whose victims might be Kuwait or Syria.' $^{15}$

In the first half of 1990 British intelligence monitored the growing tensions in the Gulf. ${ }^{16}$ However, resources were limited. During the 1980s British intelligence had focused large amounts of its reducing resources into watching the Soviet Union and countering communist activities. The Middle East had received little attention, although some resources had been directed to supporting Iraq in the Iran-Iraq war. Remaining assets were prioritised in areas where British forces were stationed or where the UK had defence commitments. By 1990 Britain had foregone its treaty obligations to go to the assistance of Kuwait in the event of external aggression and consequently Kuwait was no longer a priority area for monitoring. ${ }^{17}$ The Foreign and Commonwealth Office (FCO) had just one diplomat manning the Iraq desk, who later admitted failing to understand the level to which Iraq had remained mobilised after the war with Iran. ${ }^{18}$ The DIS had a few Gulf specialists in the Rest of World (ROW) Directorate, however they were required to cover the entire Gulf area and Lieutenant-General Derek Boorman, the former CDI, later admitted that the area 'was under-resourced'. ${ }^{19}$ Even the continuing assessments of the capability of the Iraqi navy and air force to conduct

\footnotetext{
${ }^{13}$ FAC, The Middle East After the Gulf War (London: HMSO 1991) p.vi.

${ }^{14}$ Dilip Hiro, Iraq (London: Granta Publications 2002) p.33.

${ }^{15}$ Percy Cradock, In Pursuit of British Interests, (London: John Murray 1997) p.170.

${ }^{16}$ Parry-Evans, Report, p.24.

${ }^{17}$ DIS, Intelligence Support, p.1.

${ }^{18}$ Mark Urban, UK Eyes Alpha (London: Faber and Faber 1996) p.145.

${ }^{19}$ Ibid.
} 
maritime operations, produced as part of intelligence support for the Armilla Patrol, was scaled back in early 1990 when Royal Navy permanent Gulf presence was reduced. ${ }^{20}$

The lack of resources echoed a lesson that had been identified seven years before by the Franks report. It noted that as tensions between Britain and Argentina rose in October 1981 the JIC informed the collecting agencies that increased intelligence was required on Argentinean strategies and intentions, but no further resources were allocated for that purpose. ${ }^{21}$ Consequently, at the time of invasion the SIS had only one officer in the whole of South America, GCHQ had a single analyst covering the entire South Atlantic and there was no coverage of Argentine military movements. ${ }^{22}$ The result was inadequate intelligence on Argentine forces and Falklands topography. ${ }^{23}$

It is unknown why the lesson of under resourcing was not implemented, but the problem reoccurred in the run-up to the Iraqi invasion of Kuwait. It was summarised in the DIS report: 'since Iraqi ground forces were not considered to pose a direct threat to UK interests prior to 'Granby' they were not studied in detail'. ${ }^{24}$ The lesson to be learned was identified; 'tasking priorities should allow detailed analytical coverage of all areas which could generate a crisis directly affecting UK interests'. ${ }^{25}$ However, despite the lesson identification, the 'Options for Change' defence restructuring of the British Armed Forces and reduction in defence spending

\footnotetext{
${ }^{20}$ DIS, Intelligence Support, p.2.

${ }^{21}$ Franks, Falkland Islands Review, paragraph 311.

${ }^{22}$ Urban, UK Eyes Alpha, p.145; Franks, Falkland Islands Review, paragraph 313.

${ }^{23}$ Sir Lawrence Freedman The Official History of the Falklands Campaign (Abingdon: Routledge, 2005) vol.II, p.728.

${ }^{24}$ DIS, Intelligence Support, p.12.

${ }^{25}$ Ibid.
} 
post Cold War led to further DIS staff reductions. ${ }^{26}$ Parry-Evans specifically noted that this had 'implications for the DIS of implementing the lessons learned.' 27

The deficiency in resources was compounded by the lack of formal Indicator and Warning $(\mathrm{I} \& W)$ systems for the ROW area in general, and Iraq and Kuwait in particular. ${ }^{28}$ Although this was a lesson which had not been identified by Franks, lessons surrounding warning had been examined internally for the JIC by the senior intelligence figure Doug Nicoll in the 1980s, but appeared not to have been learned. ${ }^{29}$ The DIS concluded in the post-campaign report that 'the DIS can warn that a country is preparing for military action (as happened with Granby), particularly if it is subject to an I\&W system'.${ }^{30}$ For Parry-Evans 'The lesson is that intelligence has its limitations which have to be acknowledged...An I\&W system would not necessarily have told us any more on this occasion but its formalised nature might have made the assessment more acceptable or credible'. ${ }^{31}$ He concluded 'clearly effective I\&W systems are needed in the ROW area'. ${ }^{32}$ The lesson was learned and following the end of the Gulf War effective I\&W warning systems were established throughout the ROW area. ${ }^{33}$

By the spring of 1990 relations between the UK and Iraq had become extremely tense. In March two events had worsened the relationship; the discovery of nuclear trigger devices on the way to Iraq by Customs and Excise at Heathrow; and the execution of the Observer

\footnotetext{
${ }^{26}$ Hansard, HC 25 July 1990, column 470.

${ }^{27}$ Parry-Evans, Report, p.104.

${ }^{28}$ Ibid., p. 24.

${ }^{29}$ Michael S Goodman, 'The Dog that Didn't Bark: The Joint Intelligence Committee and Warning of Aggression', Cold War History, 2007, 7/4, pp.529-551.

${ }^{30}$ DIS, Intelligence Support, p.13.

${ }^{31}$ Parry-Evans, Report, p.25.

${ }^{32}$ Ibid., p. 24.

${ }^{33}$ DIS, Intelligence Support, p.13.
} 
journalist Farzad Bazoft in Baghdad, after being convicted of spying. As a result the British Ambassador had been ordered to leave Baghdad and all Ministerial visits were cancelled.

At the same time, Iraq's economic situation had worsened. Kuwait and the UAE were frequently exceeding their OPEC quota of oil, thus keeping petroleum prices low and reducing Iraq's potential income. Kuwait used this economic advantage to place pressure on Baghdad to repay its war loans and settle their ongoing border dispute. ${ }^{34}$ By July 1990 tensions between the two countries had escalated and the DIS began regularly briefing the Joint Operations Centre (JOC) on developments. ${ }^{35}$

On 17 July, Iraq's national day, Saddam Hussein used his speech to accuse Kuwait of stabbing Iraq in the back and conspiring with Western imperialists and Zionists. ${ }^{36}$ The intelligence community noticed the threatening rhetoric but there was little response. It was not until two days later, in the DGI ROW weekly intelligence highlights, ${ }^{37}$ that the DIS reported the threat and warned that military action could not be ruled out if Kuwait did not accede to Hussein's demands. ${ }^{38}$ On 20-22 July British Defence Attaché staff from Baghdad were sent to Kuwait to examine Iraqi troop movements. They reported substantial troop movements to the south and identified 17 brigade insignia. The DIS was able to confirm from this information that all eight divisions of the elite Republican Guard were involved in the troop movements. ${ }^{39}$ The Franks report had emphasised the importance of intelligence

\footnotetext{
${ }^{34}$ FAC, The Middle East after the Gulf War, p.vi.

${ }^{35}$ Parry-Evans, Report, p.24.

${ }^{36}$ Frontline, 'Transcript of Frontline Report', 15 January 1991, available at www.pbs.org/wghh/pages/frontline/shows/longroad/etc/brink.html, accessed 22/10/2013. ${ }^{37}$ No 29/90, cited in DIS, Intelligence Support, p.2.

${ }^{38}$ Parry-Evans, Report, p. 24.

${ }^{39}$ DIS, Intelligence Support, p.2.
} 
gathering by Defence Attachés in the $1980 \mathrm{~s}^{40}$ and the report on intelligence support during Operation 'Granby' concurred stating 'This intelligence could not have been obtained from any other source'. ${ }^{41}$ The lesson from the Falklands seemed to have been learned and the report noted as one of the key lessons identified for the intelligence community that 'Attachés can provide a unique source of intelligence on military developments' ${ }^{42}$

The US had also received intelligence on troop movements. The DIA received its first report of troop movements towards the Kuwaiti border on 19 July. The Defence Intelligence Officer sent a message to the DIA Director that same day advising the activity was 'not a rehearsal' and the message was forwarded to the Chairman of the Joint Chiefs of Staff. ${ }^{43}$ The Americans did not inform their Embassy in Baghdad until the next day, nor did they share their intelligence with the British until 24 July. ${ }^{44}$

It was not until the Americans shared their intelligence that the Middle East Current Intelligence Group (CIG), the interdepartmental subcommittee of the JIC, met to produce a rapid assessment. The report was considered by the JIC the following day and assessed that Iraqi military action could not be ruled out in the 'medium term', but that Iraq's short term objective was to secure a favourable outcome at the Jeddah talks - bilateral talks between Kuwait and Iraq due to commence on $28 \mathrm{July} .{ }^{45}$ The CIA agreed with this analysis concluding that an Iraqi attack was 'highly likely' within a few days if Kuwait did not accede

\footnotetext{
${ }^{40}$ Franks, Falkland Islands Review, paragraph 150, 313.

${ }^{41}$ DIS, Intelligence Support, p.2.

${ }^{42}$ Ibid., p.12.

${ }^{43}$ Brian Shellum, Gulf War: A Chronology of Defense Intelligence in the Gulf War, 1997, available at www.dia.mil/history/features/gulf-war, accessed 20/11/2013.

${ }^{44}$ Freedman and Karsh, The Gulf Conflict p.50; Urban, UK Eyes Alpha, p.144.

${ }^{45}$ Urban, UK Eyes Alpha, p.146; Cradock, In Pursuit of British Interests, p.172.
} 
to Baghdad's demands. ${ }^{46}$ The JIC were less optimistic about the timings suggested by the CIG report and the minute circulated by the JIC to the wider government stressed a cause for concern. ${ }^{47}$ Despite this assessment the intelligence community were still surprised when, in the early hours of 2 August, Iraq invaded Kuwait, deposed the Al-Sabah ruling family and set-up a military occupation of Kuwait as an annexed territory. The first page of the released DIS report clearly states 'Granby was unexpected. ${ }^{48}$

The intelligence community's surprise was due to a lack of understanding of Iraqi intentions. Intelligence assessments had revealed that Iraq had the capability to attack, both through the strength of its army and air force, and also through its new positioning along the Kuwaiti border. However, Hussein's exact intentions remained well hidden until it was too late. Charles Powell, Thatcher's Private Secretary, later noted 'The most difficult type of intelligence to have is that about intentions. In the Iraqi invasion of Kuwait, we knew where every tank was, but we got his intentions wrong because we believed what Saddam told other Arab leaders' ${ }^{49}$ British and American diplomats and ministers had believed reassurances that Hussein had given to other Arab leaders and were fooled by his appearance of complicity in the Jeddah talks. ${ }^{50}$

The assessment of intentions also focused upon a combination of theories around the inability of Iraq to fight due to its poor economy, the belief that Hussein understood that there would be Western retaliation for his actions and that he would not wish to see his people suffer from

\footnotetext{
${ }^{46}$ CIA, 'CIA Support to the US Military During the Persian Gulf War', 16 June 1997, available at www.cia.gov/library/reports, accessed 14/12/2013.

${ }^{47}$ Urban, UK Eyes Alpha, p.146.

${ }^{48}$ DIS, Intelligence Support, p.1.

${ }^{49}$ Urban, UK Eyes Alpha, p. 150.

${ }^{50}$ Alan Munro, Arab Storm: Politics and Diplomacy Behind the Gulf War (London: I.B. Tauris 2006), p.39.
} 
the results of Western intervention, sanctions or a worsening economy. ${ }^{51}$ Each assessment fell afoul of an intelligence trap identified by Nicoll in 1982; the 'tendency to assume that factors which would weigh heavily in the United Kingdom would be equally serious constraints on countries ruled by one-party governments and heavily under the influence of a single leader, 52 - mirror-imaging. ${ }^{\text {iii }}$

There was also no intelligence providing a contrary view of Hussein's intentions due to three key factors; the nature of the regime, a lack of Humint and good Iraqi communication security (Comsec). The Granby Coordinator noted that it is 'well recognised that the "intentions" of a dictatorship are extremely difficult to discern'. ${ }^{53}$ In Iraq, Hussein as the single decision-maker kept his inner circle to a small, tight group of trusted advisors. Iraqi society was also closed and ruled by fear. Tom King, the Defence Secretary, reflected 'Iraq is a police state with awful retribution against anyone who shows dissent...when you were dealing with a state as security-minded as it is possible to be, there were bound to be problems. $^{54}$

Furthermore, there was a severe lack of Humint. With intelligence assets focused on the Soviet Union no SIS agents were in Iraq. The Humint which was gathered prior to the invasion was collected primarily through diplomatic sources and thus was heavily weighted towards Baghdad with little was known of the rest of the country. This was not a uniquely British problem. The US Senate Committee opined 'there is a tremendous need...to increase

\footnotetext{
${ }^{51}$ HCDC, Preliminary Lessons of Operation Granby, HC 287 (London: HMSO 1991) p.8.

${ }^{52}$ Goodman, 'The Dog that Didn't Bark', p.531.

${ }^{53}$ Parry-Evans, Report, p. 24.

${ }^{54}$ Urban, UK Eyes Alpha, p.156.
} 
the level of investment in human intelligence and to rebuild some of the strength that was lost in that area. ${ }^{, 55}$

After the invasion attempts to collect reliable Humint continued. As the military could not go on patrol to gather prisoners for interrogation until hostilities began, ${ }^{56}$ Humint was initially gathered from exiled Kuwaitis and expatriates. ${ }^{57}$ The DIS activated a Defence Debriefing Team which debriefed expatriates from Iraq and Kuwait as well as members of the public and commercial firms who were thought to have knowledge applicable to the crisis. This exercise produced a large amount of valuable information which was widely distributed in Britain and the US. ${ }^{58}$

A number of Humint sources were also used to clarify Imint allowing refined targeting by helping to identify mosques and hospitals for the coalition forces to avoid. ${ }^{59}$ They also provided detailed sketches, locations of bunkers underneath facilities, including the Iraqi Air Force headquarters, and advised of the Iraqi practice of stringing communications cable under bridges rather than under the river beds - a deciding factor in the decision to target bridges in Baghdad. ${ }^{60}$ The MoD also demonstrated lessons had been learned from the Falklands crisis. In 1982 there had been a severe shortage of Spanish speakers able to act as translators. Once hostilities began in the Gulf 93 Arabic speaking personnel and 78 Kuwaiti

\footnotetext{
${ }^{55}$ Senate, Review of Intelligence Organization, p.4.

${ }^{56} \mathrm{HCDC}$, Implementation, p. 24.

${ }^{57}$ FAC, Gulf Crisis, p.1, 3.

${ }^{58}$ DIS, Intelligence Support, p.8.

${ }^{59}$ US Department of the Army Office of the Deputy Chief of Staff for Intelligence, Annual Historical Review 1 October 1990 to 30 September 1991, The National Security Archive, Briefing Book No.39, p.3.

${ }^{60}$ US Department of Defence, Conduct of the Persian Gulf War: Final Report to Congress (Washington: United States Government Printing 1992) p.225.
} 
civilians were deployed to work in hospitals and POW camps to aid in gathering Humint for the intelligence community. ${ }^{61}$

Some human sources provided information in far greater volume than expected; refugees, border crossers and the Kuwaiti resistance provided a large amount of intelligence of value for the tactical intelligence cells. To aid the process of Humint collection from these sources the Defence Debriefing Team went to Saudi Arabia to train the Saudis to debrief the flow of Iraqi deserters. ${ }^{62}$ The DIS concluded a key lesson to be learned: 'The Defence Debriefing Team is a valuable asset in emergencies and will be kept in being for use at short notice; it may be required to provide training assistance to allies. ${ }^{, 63}$ However, the team remained manned by reservists who were called up on a voluntary basis. ${ }^{64}$

Interrogation capabilities had also recently improved through the creation of the Joint Services Interrogation Organisation which had been provided its own vehicles and communications for deployment. ${ }^{65}$ However, for political reasons detailed interrogation was not permitted on POWs held in the UK nor were POWs allowed to be brought back to the UK for the same purpose. ${ }^{66}$ The DIS concluded: 'Intelligence gained through interrogation can make an important contribution to the overall picture and its use should not be unnecessarily limited. ${ }^{67 i v}$

\footnotetext{
${ }^{61}$ HCDC, Preliminary Lessons, p.xxiv.

${ }^{62}$ DIS, Intelligence Support, p.9.

${ }^{63}$ Ibid., p.14.

${ }^{64}$ HCDC, Implementation, p. 25.

${ }^{65}$ Ibid.

${ }^{66}$ DIS, Intelligence Support, p.9.

${ }^{67}$ Ibid., p.14.
} 
The lack of intelligence on Hussein's intentions prior to invasion was compounded by the training and discipline of Iraqi Comsec. During the Iran-Iraq war the Americans had advised the Iraqis on how to avoid being intercepted by space based intelligence gathering and provided lessons on secure communications, including the use of fibre-optic landlines. The Iraqis continued to exploit this knowledge throughout the Gulf War campaign. ${ }^{68}$ In particular, a landline was quickly installed from Kuwait City to Baghdad specifically to avoid communication interception. The result was secure communications through which intentions could not be overheard until an SBS raid in January 1991, codenamed Operation Maude, was used to blow up part of the underground communications cable forcing the Iraqis to use radio communications. ${ }^{69}$ The DIS report concluded 'a force which is poised for attack, and which uses Comsec well, can always hide its exact intentions unless these are revealed through Humint at a high level'. ${ }^{70}$

Once the military campaign began very little further intelligence on Hussein's intentions was gathered. At times, this proved frustrating for British military commanders who wanted to know the most they could about their enemy and their leader. ${ }^{71}$ Some intelligence was gathered by the US National Security Agency (NSA) by intercepting Hussein's phone calls to the Iraqi Ambassador to the United Nations, Nazar Hamdoon. The intercepts were sent from the NSA to London where they were circulated on a tight distribution. ${ }^{72}$

POST INVASION, PRIOR TO HOSTILITIES: 2 AUGUST 1990 - 16 JANUARY 1991

\footnotetext{
${ }^{68}$ Richard J Aldrich, GCHQ (London: Harper Press 2011) p.466-467

${ }^{69}$ Ibid., p.61.

${ }^{70}$ DIS, Intelligence Support, p.2.

${ }^{71}$ General Peter De la Billière, Storm Command (London: Harper Collins 1992) p.24-25.

${ }^{72}$ Urban, UK Eyes Alpha, p.170.
} 
Once Iraq had invaded Kuwait the central intelligence machine sprung into action. The Franks report had been critical of the organisation during the Falklands crisis, describing it as 'too passive in operation to respond quickly and critically to a rapidly changing situation which demanded urgent attention, ${ }^{, 73}$ and recommending a review of the structure and the position of the JIC Chairman. ${ }^{74}$ As a result the JIC was expanded, removed from the authority of the FCO and placed within the Cabinet Office with the central intelligence machinery rebuilt by Percy Cradock, the Chairman of the JIC and Foreign Advisor to the Prime Minister. The crisis offered Cradock the opportunity to demonstrate that lessons had been learned from Franks and that the workings of the JIC had radically improved. The Middle East CIG began meeting at 4am to produce daily intelligence bulletins which were used to inform the 6am JIC meeting. In turn the JIC prepared a briefing for senior officials at 8:30am who then produced an agenda for a Ministerial meeting at $10 \mathrm{am} .{ }^{75}$ In his dual role, Cradock attended both the JIC and War Cabinet meetings and the series of meetings aided in achieving good cross-Whitehall intelligence liaison. The Franks report had criticised the intelligence assessment machinery for poor links with the FCO and MoD which had led to assessment staff being unable to fully take into account relevant diplomatic and political developments as well as foreign press treatment of sensitive issues. ${ }^{76}$ The new processes and structure seemed to have rapidly improved the central intelligence machine. Parry Evans wrote 'the general assessment by the Cabinet Office of the operation of the Government machinery during the crisis is that it worked well. One principle reason that it did so was that care was taken from the start to take account of the lessons identified in 1982. ${ }^{77}$ However, more lessons must also have been identified at the end of the war as a new Cabinet committee

\footnotetext{
${ }^{73}$ Franks, Falkland Islands Review, paragraph 318.

${ }^{74}$ Ibid., paragraph 319.

${ }^{75}$ John Major, The Autobiography (London: Harper Collins 1999) p.234.

${ }^{76}$ Franks, Falkland Islands Review, paragraph 317.

${ }^{77}$ Parry-Evans, Report, p.13.
} 
was established shortly afterwards to oversee the intelligence services. ${ }^{78}$ By 2004 Butler warned that the central intelligence machinery was in danger of becoming too large and unwieldy, although no changes to JIC membership were recommended. ${ }^{79}$

The DIS also reacted promptly to the invasion, unlike during the invasion of the Falklands. ${ }^{80}$ Contingency planning had envisaged three main progressive stages in any crisis and the conceptual framework was proved correct by 'Granby'. ${ }^{81}$ A provisional crisis cell was established on 3 August with the first intelligence summary issued the following day. The crisis cell was formalised overnight on 5/6 August and continued to produce twice daily summaries. When military operations began in January these were increased again to four summaries a day and augmented by a fifth offering strategic damage assessments. ${ }^{82}$ Staffing remained relatively low; for the first six months the Crisis Cell was manned by three officers and three support staff per watch. Between January and February 1991 each watch was increased to ten officers and eight support staff. By this time, 50 percent of the officers and 25 percent of the support staff were provided by the Warsaw Pact and the Scientific and Technical Intelligence Directorates of the DIS. ${ }^{83}$ The DIS also had to provide augmentees to the JOC, HQ BFME, the national Embargo Monitoring Intelligence Cell and the Cabinet Office Joint Intelligence Organisation. Consequently, the DIS report concluded that 'By January the supply of augmentees was totally exhausted' and in addition 'It is uncertain whether the DIS (even with MoD augmentation) would have the resources to provide intelligence support for two simultaneous crises. ${ }^{, 84}$ The finite source of sufficiently trained

\footnotetext{
${ }^{78}$ Urban, UK Eyes Alpha, p.183.

${ }^{79}$ Butler, Review of Intelligence on Weapons of Mass Destruction, p.144.

${ }^{80}$ Freedman Official History of the Falklands, p.728.

${ }^{81}$ DIS, Intelligence Support, p.3.

${ }^{82}$ Ibid., p.11.

${ }^{83}$ Ibid., p.4.

${ }^{84}$ Ibid., p.4-5.
} 
augmentees was highlighted: 'Sufficient augmentees, with clearly defined assignments, must be earmarked to meet all foreseeable crisis requirements; they should be aware of, and trained in, their crisis role. ${ }^{85}$ It is unknown whether this training occurred but the lesson report from Operation 'Telic', the British codename for the 2003-2009 Iraq War, revealed that better training and preparation was still required. ${ }^{86}$

The DIS also ensured cross-intelligence agency and cross-Whitehall liaison. A Director General of Intelligence (DGI) briefed the Cabinet at least daily, with a brief that mirrored the CDI's MoD briefings. ${ }^{87} \mathrm{He}$ also attended the JIC meetings and one of the three key tasks defined in the DIS crisis planning document was 'To provide Ministers, CDS [Chief of the Defence Staff] and MoD Central Staffs with as complete a military intelligence picture as they require. ${ }^{88}$ How this structure changed over the course of the 1990's is unknown but by 2004 the Butler inquiry assessed that the DIS were still not sufficiently incorporated into the intelligence community. ${ }^{89}$

The immediate intelligence need was for assessments on the strengths, efficacy, procedures and capabilities of the Iraqi army. Unlike the advanced and detailed assessments which were routinely published on the major targets of the USSR and Warsaw Pact, existing assessments on Iraq were limited. ${ }^{90}$ Thirteen support groups were established to advise and assist the DIS in the preparation of detailed assessments and by January 1991 the DIS had issued around

\footnotetext{
${ }^{85}$ Ibid., p.13.

${ }^{86}$ Lt General Chris Brown, 'Operation Telic Lessons Compendium', available at https://www.gov.uk/government/publications/operation-telic-lessons-compendium, n.d., p.82. ${ }^{87}$ DIS, Intelligence Support, p.6.

${ }^{88}$ Ibid., p.9.

${ }^{89}$ Butler, Review of Intelligence on WMD, p.158.

${ }^{90}$ DIS, Intelligence Support, p.2.
} 
300 new background studies. ${ }^{91}$ Completion of this task revealed an additional deficiency; a considerable depth of technical knowledge was required on a wide variety of eastern and western weapon systems used by the Iraqis and the DIS was unprepared for the latter requirement. The DIS report acknowledged the lesson to be learned: 'The DIS needs to expand its expertise on weapons systems exported by the west to potential enemies. ${ }^{92}$

In reflecting upon the requirements of such assessments Parry-Evans listed as one of his key lessons: 'a need for a data base, comprising both quantitative and qualitative aspects and covering a wide range of countries' ${ }^{93}$ The DIS report also stated that for analytical coverage of all areas there should include an assessment of 'the quality and effectiveness of a potential enemy, not just his orbat [order of battle]. ${ }^{94}$ In contrast the CIA had monitored Iraqi deployments during the 1980s and written hundreds of reports, which from the beginning of August 1990 were provided to the US military. ${ }^{95}$

One of the specific areas which required immediate assessment was Iraq's non-conventional weapons systems and capabilities; missiles, nuclear, biological and chemical weapons. The Iraqi defence newspaper had boasted 'Iraq's arsenal contains surprises which will astonish our enemies ${ }^{, 96}$ and the intelligence community was aware that the Iraqi government had used chemical weapons during the Iran-Iraq war and retained considerable chemical and biological weapon capability. ${ }^{97}$ Collection of intelligence on the non-conventional threat had already received a level of priority and the intelligence community had assessed that Hussein was

\footnotetext{
${ }^{91}$ Ibid., p.3,10.

92 Ibid., p.15.

${ }^{93}$ Parry-Evans, Report, p.84.

${ }^{94}$ DIS, Intelligence Support, p.12.

${ }^{95}$ CIA, 'CIA Support'.

${ }^{96}$ Major, The Autobiography, p.232.

${ }^{97}$ HCDC, Implementation, p.ix,26.
} 
seeking to develop a nuclear weapon ${ }^{98}$ or acquire WMD via an extensive international procurement network. ${ }^{99}$

The Butler report revealed that a number of JIC assessments were produced during this time: 'the intelligence agencies contributed to a steady flow of intelligence covering Iraqi procurement activities, attempts to break United Nations sanctions, concealment of prohibited programmes and plans for handling UNSCOM and IAEA inspections. ${ }^{, 100}$ On 27 September 1990 an assessment of Iraq's nuclear programme concluded that without significant external assistance it would take Iraq at least three years to establish a production capability for fissile material. ${ }^{101}$ However, the JIC also assessed that the Iraqi regime could implement a "crash programme' which would provide Iraq the capability of making an untested nuclear weapon by the end of $1990 .^{102}$

Following the IAEA inspection in November 1990 the JIC produced a new assessment. It noted, on 4 December, that 'We have no intelligence that would cause us to change our assessment of Iraq's current nuclear capability. Without significant foreign assistance, Iraq is still at least three years away from the capability to produce fissile material. ${ }^{, 103}$ The inspection also confirmed to the JIC that by 22 November no 'crash programme' had begun, but if it began immediately the earliest a single un-tested device could be available would be mid-1991. ${ }^{104}$

\footnotetext{
${ }^{98}$ HCDC, The Conflict in the Gulf: Minutes of Evidence, 6 March 1991, HC287 (London: HMSO 1991) p.10-11.

${ }^{99}$ Cradock, In Pursuit of British Interests, p.169.

${ }^{100}$ Butler, Review of Intelligence on WMD, p.42.

${ }^{101}$ Cited in ibid., p.42.

102 Ibid., p.43.

${ }^{103}$ Ibid.

104 Ibid.
} 
The intelligence community also assessed Iraq's chemical weapons programme. The JIC had some existing knowledge but an intelligence report received in November 1990 added further detail. ${ }^{105}$ The JIC picked up many of the figures from this report. The Butler report also revealed JIC assessments were made of Iraq's ballistic missile programme, although intelligence was limited. On 20 September 1990 the JIC assessment stated 'There are considerable uncertainties about Iraq's current ballistic missile capability and deployments. ${ }^{106}$ It approximated that Iraq had a stockpile of around 700 ballistic missiles. However, later appraisals of the assessments reveal a fluctuating level of assessment accuracy. The Special Commission on Iraq confirmed the existence of a number of agents which had been identified by the JIC but that capabilities had been overstated. No evidence of weaponised biological agents was found, whilst others, including the effort and scale of progress with nuclear weapons, had been understated. ${ }^{107}$ The Butler report criticised the intelligence community, in particular the JIC, for basing much of its assessment on Iraq's nuclear weapons programme at this time on the incorrect assumption that the Iraqi's would only use one route to enrich fissile material. ${ }^{108}$ Butler also revealed that the intelligence report received in November 1990 on Iraq's chemical weapons programme was incorrect on a number of counts and that estimates of the size of Iraqi chemical agent stockpiles assumed that no chemical agent stocks had been left over from the Iran-Iraq war. ${ }^{109}$

Intelligence resources also began to focus upon military targeting. On 6 August the DIS began unilaterally working on a targeting study and produced over 300 target graphics in the

\footnotetext{
${ }^{105}$ Ibid., p.45.

${ }^{106}$ Cited in ibid., p.49.

${ }^{107}$ Cradock, In Pursuit of British Interests, p.176.

${ }^{108}$ Butler, Review of Intelligence on WMD, p.42.

${ }^{109}$ Ibid., p.46.
} 
months before hostilities began. ${ }^{110}$ The work was promptly produced to provide the opportunity for UK input into joint targeting discussions with the US. However, the Americans decided to delegate target selection to the command in the Gulf effectively excluding the British from the target selection process. ${ }^{111}$ The Granby Coordinator speculated that the reason for exclusion may have been due to US Central Command (CENTCOM) Opsec (operation security) or an incompatibility of rank; the highest ranked British intelligence specialist in theatre was a Lieutenant Colonel (Lt Col). Parry-Evans observed 'Our American friends place great emphasis on rank and there is a gulf between Lt Col and full Colonel...There are obvious political factors to be addressed here.' ${ }^{112}$

Although the unused target graphics were later praised by the Americans the exercise of producing the targeting study revealed a national capability weakness. Whilst much targeting work had previously been completed within the NATO area it had become clear that the work also needed to extend to out of area (OOA) capability. ${ }^{113}$ In addition, throughout the process the interface between operations and intelligence had been poor with the DIS taking a lead by default. Subsequently, two key lessons were identified. Firstly, proposals were put together to extend target sets to OOA operations. ${ }^{114}$ The DIS also identified the need for a clearer structure: 'A MoD targeting programme is required and a formal structure needs to be created to undertake targeting on a long term basis against an array of potential target countries. ${ }^{, 15}$ Whether the programme was created is unknown but targeting difficulties continued to emerge 12 years later in Iraq. ${ }^{116}$

\footnotetext{
${ }^{110}$ DIS, Intelligence Support, p.5.

${ }^{111}$ Parry-Evans, Report, p. 27.

112 Ibid.

${ }^{113}$ DIS, Intelligence Support, p.5.

${ }^{114}$ Ibid.

115 Ibid., p.13.

${ }^{116}$ Brown, 'Operation Telic Lessons', p.70.
} 
A different form of intelligence which was vital for the military was Imint. Imint had already proved fundamental in convincing Saudi Arabia to request American and British military assistance when, shortly after the invasion, the Americans shared satellite imagery of Iraqi tank movements to the Saudi border. ${ }^{117}$ Throughout the campaign imagery was collected from satellites, aircraft and drones. Although the British intelligence community had no access to satellite photography of its own it was fortunate, as part of the coalition, to have access to the intelligence available from the US satellite system. The Imint provided vital data for strategic planning. It was particularly significant before the coalition offensive began as no aerial Imint collection platforms could be used in enemy territory prior to hostilities. ${ }^{118}$

\section{HOSTILITIES: 17 JANUARY 1991 - 28 FEBRUARY 1991}

Once the hostilities began aerial reconnaissance was used. Again, the British were highly reliant upon US image collection, including from two new prototypes of the Joint Surveillance and Target Radar Attack System (JSTARS) which provided processed, real-time intelligence on moving targets. ${ }^{119}$ On the other hand, the UK Midge drones failed to provide any useful Imint at all. Major General Rupert Smith reported to the HCDC that the Midge often failed to return and when it did the imagery was usually unusable. ${ }^{120}$ This was identified as a lesson by Smith although not referenced in the DIS report or by Parry-Evans.

Nonetheless, the Midge was soon replaced by the Phoenix. ${ }^{121}$

\footnotetext{
${ }_{117}^{11}$ Margaret Thatcher, The Downing Street Years (London: Harper Collins 1993) p.820.

${ }^{118}$ Anthony H. Cordesman and Abraham R. Wagner, 'The Lessons of Modern War Volume IV: The Gulf War', 1994, available at csis.org/publication/lessons-modern-war-volume-ivgulf-war-introduction, accessed 23/10/2013, p.307.

${ }_{119}$ HCDC, Implementation, p.20.

${ }^{120}$ Ibid., p.19.

${ }^{121}$ Ibid.
} 
On the other hand, the British military were able to assist with reconnaissance via manned aircraft. Six Tornado GR1a, a new aircraft for the RAF, flew 123 night time low level sorties using infra-red technology to provide intelligence on force dispositions and to hunt for Scud missiles. ${ }^{122}$ In addition, a number of Jaguar aircraft were also used for reconnaissance sorties. ${ }^{123}$ These assets were much needed; the US military also had to divert reconnaissance assets from counternarcotics operations to the Gulf in order to meet the requirement for reconnaissance missions. ${ }^{124}$ To coordinate the various collection platforms for Imint across the coalition CENTCOM held a Daily Aerial Reconnaissance and Surveillance (DARS) conference which UK representatives attended. ${ }^{125}$

The only difficulty for the British intelligence community was a severe shortage of photographic interpreters (PI) in order to examine the raw Imint and provide an appropriate assessment. The result was not only a large reliance on US collection but also upon US analysis. The DIS report highlighted a key lesson to be learned: 'Crisis planning must take account of limitations on PI availability and the need to depend in large part on the output of US Agencies. 126

Sigint continued to be exploited operationally and tactically throughout the campaign too. Although the UK did not have space-borne Sigint collection capability the British utilised intelligence collected from the Nimrod Rs, GCHQ's listening base in Cyprus and by US collection platforms for operational planning. Hine noted the particular success of the Nimrod

\footnotetext{
${ }^{122}$ Hine, 'Despatch', p.G42.

${ }^{123}$ Parry-Evans, Report, p.25.

${ }^{124}$ Shellum, Gulf War, entry for 30 November 1990.

${ }^{125}$ DoD, Conduct of the Persian Gulf War, p.391.

${ }^{126}$ DIS, Intelligence Support, p.13.
} 
Rs, which operated out of Akrotiri at 'intensive rates' for seven months, and praised the high quality of the collection and the ability to provide data in near real time through downlinking. ${ }^{127}$

However, overall tactical Sigint was less successful than operational Sigint. Tactical Sigint units from all three services were deployed between August 1990 and January 1991 but planning lagged behind the operational deployment making it difficult to be fully exploited. In addition, there was an ongoing difficulty in providing enough translators to assess all the collected intelligence for tactical purposes. After the campaign the DIS concluded that three lessons were to be drawn:

a. Future OOA [out of area] operational plans should include Tactical Sigint elements.

b. There were insufficient linguists to meet the many demands placed upon them.

c. There is a need for a central intelligence management body for the allocation of Tactical Sigint elements. ${ }^{128}$

Whilst it is unknown whether these lessons were learned much work was done following 'Granby' to create a stronger DIS central intelligence management structure and procedures. However, the problem of insufficient linguists reoccurred in Iraq in 2003 and the lessons study from Operation 'Telic' concluded: 'Insufficient linguists were available to support the intelligence function., ${ }^{129}$

\footnotetext{
${ }^{127}$ Hine to Vincent, 20 May 1991, in Parry-Evans, Report, Annex B, p.9-10.

${ }^{128}$ DIS, Intelligence Support, p.8.

${ }^{129}$ Brown, 'Operation Telic', p.69.,
} 
In the autumn of 1990 British intelligence began to plan psyops against the Iraqis. Initially British psyops capability consisted of a single officer based at the Intelligence Corps training centre in Kent. Eventually the British military contributed 12 personnel, although the US committed several hundred personnel from its $4^{\text {th }}$ Psyops Group. ${ }^{130}$ The role of the military team was to undermine the morale of Iraqi troops and was primarily achieved through the dropping of leaflets which would warn Iraqi soldiers against fighting, to stay away from their equipment because it was likely to be a target of coalition air strikes and offering safe conduct passes to those who surrendered. As the military could not fly into enemy territory before the offensive began 25,000 leaflets were first sent by hot air balloon. ${ }^{131}$ During the war 29 million leaflets were dropped by the coalition into the Kuwaiti theatre of operations. ${ }^{132}$ These operations proved highly successful and many Iraqi soldiers promptly surrendered and were found holding a leafleted safe conduct pass. ${ }^{133}$ Although the benefits of psyops were not recognised in the DIS or Granby Coordinator reports, the lesson had been learned; immediately after the war 15 (UK) PSYOPS Group was established to retain and enhance the UK psyops capability. However, lessons identified from 'Telic' reveal that greater investment was still required, including developing a British leafleting capability for hostile environments. $^{134}$

Once hostilities began the greatest challenge for the intelligence community was dealing with the quantity of raw intelligence and demands for fast paced intelligence assessments, particularly Bomb Damage Assessments (BDA). BDA was important for the Joint Forces Commander General Schwartzkopf because he did not want to commit troops to a ground

\footnotetext{
${ }^{130}$ Urban, UK Eyes Alpha, p.163.

${ }^{131}$ Ibid.

${ }^{132}$ DoD, Conduct of the Persian Gulf War, p.622.

${ }^{133}$ Urban, UK Eyes Alpha, p. 177.

${ }^{134}$ Brown, 'Operation Telic Lessons', p.71.
} 
campaign until the air campaign had reduced the effectiveness of the Iraqi Republican Guard by 50 percent. However, BDA staff were overloaded and even when the Intelligence Collection Centre increased its staff from 170 to 600 people rushed assessments were often inaccurate, putting at risk air crews and wasting valuable weapons revisiting targets. ${ }^{135}$ This was partly due to the limitations of reliance upon satellite imagery systems for the task; a tank may have moved between satellite orbits or flames would go out between one pass and another. ${ }^{136}$ These systems were meant for strategic surveillance, not tactical reconnaissance.

Although the DIS targeting cell moved into BDA at the start of hostilities the UK was highly dependent upon US analysts. ${ }^{137}$ In addition, as the RAF did not possess the appropriate intelligence gathering equipment the British intelligence community remained reliant upon US collection platforms. ${ }^{138}$ This caused a number of problems, including that the DIS encountered difficulties in getting reports from CENTCOM on tactical BDA in a timely manner. ${ }^{139}$ The identified lesson stated 'an agreed national BDA methodology is required (aligned, if possible, to the US). ${ }^{140}$ The lessons report from 'Telic' reveals that a UK BDA process and policy was in place by 2003 but that it required further review. ${ }^{141}$

More broadly, there was much difficulty in the distillation and dissemination of intelligence. This echoed difficulties experienced during 1982, whereby delays in the dissemination of tactical and strategic intelligence had eventually led the captain of Uganda to complain via telegram that delayed classified information meant that his ship 'had apparently sailed

\footnotetext{
${ }^{135}$ HCDC, Implementation, p.xxii.

${ }^{136}$ Urban, UK Eyes Alpha, p.172.

${ }^{137}$ DIS, Intelligence Support, p.6.

${ }^{138}$ HCDC, Implementation, p. 25.

${ }^{139}$ DIS, Intelligence Support, p.11.

${ }^{140}$ Parry-Evans, Report, p.26.

${ }^{141}$ Brown, 'Operation Telic Lessons', p.70.
} 
through a minefield off Stanley'. ${ }^{142}$ In a repeat performance in 1990-1991 De La Billière told the HCDC 'there was so much [intelligence] available in the end that it was very difficult to cope with it and to extract from it the detail which was required at lower command levels., 143 Parry-Evans agreed. ${ }^{144}$ Although this was partly the result of US organisation, there was also an insufficient number of trained British intelligence personnel to process the intelligence data. Hine identified that all three services lacked in suitable personnel; the Royal Navy had shortfalls afloat and ashore which were filled with Intelligence augmentees; the Army were eventually able to man units but the flow of intelligence to JHQ and HQ in theatre was slow; the new RAF Intelligence Branch was supplemented by the RAF Volunteer Reserve with no opportunity for roulement. ${ }^{145}$ At the end of the Gulf War an officer was appointed to increase intelligence training across all services, including the running of full scale military exercises. ${ }^{146}$ However, Brown concluded that 'Telic' had exposed the need for still further training. ${ }^{147}$

Adding to these existing distillation difficulties were problems associated with Opsec, intelligence sensitivity and classification issues. The Opsec difficulties were two-fold; over rigorous security surrounding planning left requests for intelligence very late, whilst overcautious sensitivity regarding intelligence often stopped intelligence reaching the military. The DIS and DIA were both refused access to a number of reports leading the MoD to conclude 'Opsec is to be encouraged but not to the point where the enemy knows more of our own operations than does the home side. In this case Opsec was carried to extremes'. ${ }^{148}$

\footnotetext{
${ }^{142}$ Freedman, Official History of the Falklands, p.728.

${ }^{143}$ HCDC, Preliminary Lessons, p.16.

${ }^{144}$ Parry-Evans, Report, p.26.

${ }^{145}$ Hine to Vincent, in ibid., annex B, p. 10.

${ }^{146}$ HCDC, Implementation, p.23.

${ }^{147}$ Brown, 'Operation Telic Lessons', p.69.

${ }^{148}$ DIS, Intelligence Support, p.6.
} 
In addition, many intelligence reports were classified at a level which required sanitisation before dissemination leaving those at JHQ more informed than those in theatre. There was also a similar difficulty within the coalition whereby the widespread application of the US 'NOFORN' (no foreigners) and UK 'EYES A' (UK citizens only) classifications hindered cross-coalition intelligence sharing. The lesson recorded was 'measures were applied to an excessive extent and inhibited intelligence analysis. Opsec must not be carried to extremes. $^{149}$

Owners of intelligence and intelligence assets also failed to always recognise the value of sharing information with others. Some of the manpower and intelligence gathering assets were controlled by single services or commands. Major General Rupert Smith reported to the HCDC:

The owner of the piece of kit, the single piece of kit, tended to want to use it for his own purposes and his staff were supporting him and not recognising the needs of someone and in fact that they owned the information that that someone could have. ${ }^{150}$

The management of intelligence was highlighted by the post-operational DIS report which concluded that 'Granby' had shown the need for more effective central management of defence intelligence, something which had been previously agreed but not achieved. The key lesson identified was 'Scarce MoD-controlled intelligence resources must be used to best advantage; steps are in hand to ensure that the overall defence intelligence effort is coordinated more effectively. ${ }^{151}$ Following the Gulf War all assets were centralised under

\footnotetext{
${ }^{149}$ Ibid., p.13.

${ }^{150}$ HCDC, Implementation, p.22.

${ }^{151}$ DIS, Intelligence Support, p.12.
} 
the CDI and an intelligence division was created within the Permanent Joint Headquarters (PJHQ) at Northwood in 1996. ${ }^{152}$ However, by 2003 concerns were again raised over the growing intelligence structure, across DIS, PJHQ and in theatre, and the lesson identified by Brown was that a review was required to ensure greater 'fusion' between the three. ${ }^{153}$

Dissemination problems were compounded by a lack of secure communications. From the outset of the crisis there was inadequate communication links between the DIS, JHQ and the US intelligence organisations. There was a particular shortage of secure voice links to US agencies because the US had moved from a system, to which the DIS had access, to a new system which they had previously refused to release to the UK. The hindrance was only partially overcome by installing one new terminal in the DIS which was manned on a 24-hour basis by a US liaison or post exchange officer. ${ }^{154}$ Once the crisis was over the terminal was removed but the lesson identified by the MoD stated 'The communications links established in Granby must be maintained and secure voice links with the US improved. ${ }^{155}$

Working with the Americans proved extremely important throughout the campaign and was an enduring lesson. Early on in the crisis there had been a good working relationship between US President Bush and UK PM Thatcher which had set the tone of relations. The JIC also worked with the CIA to provide estimates on WMD and Cradock had visited the US National Security Adviser, Brent Scowcroft, his deputy, Bob Gates, and the head of the CIA, Bill Webster, in October 1990. A British Defence Intelligence Liaison Staff was set-up in Washington with mirrored DIA and CIA representatives in London to ensure close communications between the capitals on strategic thinking and to provide advice on the crisis

\footnotetext{
${ }^{152} \mathrm{HCDC}$, Implementation, p.22.

${ }^{153}$ Brown, 'Operation Telic', p.85.

${ }^{154}$ DIS, Intelligence Support, p.7.

${ }^{155}$ Ibid., p.14.
} 
management systems established and the necessary points of contact. ${ }^{156}$ The DIS report concluded:

The close relationship between the DIS and US agencies in Washington meant that we were not only able to provide HQ BFME with a UK assessment of the situation for use in consultation with the Allied Commander but we were fully aware of the national assessment in Washington and to some extent able to influence that assessment. $^{157}$

US intelligence analysts were also deployed to JHQ as well as British analysts to the Operations Intelligence Crisis Cell in CENTCOM. ${ }^{\vee}$ There was integration between the US Central Air Force and British air intelligence staffs ${ }^{158}$ and from 17 January the US was approved to release BDA intelligence to the UK. ${ }^{159}$ Hine described the relationship as 'special' and concluded: 'The ready availability to us of high-quality intelligence reflected the mutual trust and rapport established between our intelligence communities over the years. ${ }^{160}$ This availability proved vital, with the Americans utilising collection platforms that the British could not afford and providing far greater numbers of man power. One British analyst advised: 'Over 90 percent of what was in my reports was American material. If we didn't have the Americans, I'd have nothing to write about...In the intelligence world the Americans have all the cards. Without them, we'd be little better than Belgium. ${ }^{161}$ The lesson identified within the DIS report also emphasised the US relationship:

\footnotetext{
${ }^{156}$ Ibid., p. 11 .

${ }^{157}$ Ibid.

${ }^{158}$ Hine to Vincent in Parry-Evans, Report, annex B, p.10.

${ }^{159}$ Shellum, Gulf War, entry for 17 January 1991.

${ }^{160}$ Hine to Vincent in Parry-Evans, Report, annex B, p.9.

${ }^{161}$ Urban, UK Eyes Alpha, p.181.
} 
Close cooperation between Allied intelligence organisations, and especially with those in the US is essential in a crisis: the UK needs to take full advantage of the much greater American effort...the special UK/US intelligence relationship must be maintained. ${ }^{162}$

This lesson was kept in mind into the 2000s. The lesson compendium from Operation 'Telic' reveals that after 2001 UK staff were quickly embedded in US manned coalition headquarters and liaison in US headquarters became a full-time basis. ${ }^{163}$

Working with other allies' intelligence agencies during 'Granby' was also important; the Soviets provided data on the Scud missile system, Israel shared a detailed psychological profile of Hussein which one analyst described as 'one of the most useful documents I saw in the entire war', ${ }^{164}$ the French flew reconnaissance sorties in Jaguars whilst their Puma Helicopters provided tactical data. ${ }^{165}$ The Palestinians provided intelligence on the wider impact of the crisis for terrorism and insurgency and many Arab states provided counterintelligence. ${ }^{166}$ To coordinate counterintelligence operations amongst the coalition Joint Counterintelligence Liaison Offices were set-up in Saudi Arabia. The British also shared intelligence in return. The DGI (ROW) carried out briefing tours to the Gulf, presenting British intelligence assessments to Egypt, Saudi Arabia, UAE, Bahrain, Qatar and Oman. ${ }^{167}$

\footnotetext{
${ }^{162}$ DIS, Intelligence Support, p.14.

${ }^{163}$ Brown, 'Operation Telic', p.32.

${ }^{164}$ Urban, UK Eyes Alpha, pp.157-158.

${ }^{165}$ Cordesman and Wagner, 'The Lessons of Modern War', p.305.

${ }^{166}$ Alan Munro Keep the Flag Flying (London: Gilgamesh 2012) p.249.

${ }^{167}$ DIS, Intelligence Support, p.7.
} 
There was also a particularly close intelligence relationship with the Saudis. Early on in 'Granby' the head of the SIS, 'C', had visited his counterpart, Prince Turki, in Saudi Arabia to secure a smooth working relationship and compare intelligence on Saddam. ${ }^{168}$ Upon negotiation from the British Ambassador a British Intelligence Corps liaison was also established in Prince Khalid's, the Commander of the Arab forces, headquarters. ${ }^{169}$ As part of their contribution to the coalition the Saudi's ran aerial reconnaissance missions and conducted surveillance missions along Saudi Arabia's border and over Iraqi territory. The Royal Saudi Air Force intelligence personnel also interpreted much of its collected photography and Saudi troops were responsible for the interrogation of many of the Iraqi deserters. ${ }^{170}$ The DIS end of operation lessons report noted 'European and Arab participation in Coalition forces and the political importance of [retained] proved the value of connections established by the DIS with many other national intelligence agencies. ${ }^{171}$ Parry-Evans agreed and stated the key lesson: 'The importance of the UK/US intelligence link cannot be overemphasised, but many of our intelligence links with a wide range of countries were of particular value, pointing the need to maintain and foster such links. ${ }^{172}$ Following investigations on both sides of the Atlantic on the intelligence on Iraqi WMD in 2003, many of these links were revealed as retained.

\section{CONCLUSION}

Overall, the Gulf War brought the intelligence community a number of successes, including good working relationships across the coalition nations and new achievements in psyops. It

\footnotetext{
${ }^{168}$ Munro, Keep the Flag Flying, p.221.

${ }^{169}$ Munro, Arab Storm, p.93.

${ }^{170}$ DoD, Conduct of the Persian Gulf War, p.394.

${ }_{171}^{17}$ DIS, Intelligence Support, p.11.

172 Parry-Evans, Report by the Granby Coordinator, p.83.
} 
also demonstrated that much had been learned since the Franks report with a restructured and more active central intelligence machine and utilising military attachés for valuable intelligence collection. However, the war also revealed that a great many more lessons needed to be learned, including the development of a national targeting capability and national BDA methodology. Butler would also go on to identify still further lessons 13 years later.

The Parry-Evans and DIS reports offer a glimpse into the secretive world of intelligence during a time of crisis which is not yet outside the 30 , reducing to 20 , year rule. Unlike the external inquiries of Franks and Butler they also provide an insight into the intelligence community's self-reflexivity in considering its own lessons from experience. They reveal that identified lessons offered a mix of positive learning, including the value of the Defence Debriefing Team, and negative learning, where failings were highlighted for immediate or future improvement. They crossed hierarchical boundaries with lessons identified at strategic, operational and tactical levels, within centrally managed intelligence and in theatre. Although the reports were not exhaustive - still further lessons emerged within the HCDC which had not been mentioned in either report including the failings of the Midge drone - they were extensive and provided a comprehensive checklist for implementation for the Granby Coordinator and the CDI.

As part of the MoD, both reports focused upon the lessons learned in defence intelligence with only a few lessons identified for the wider intelligence community. The MoD and armed services had long since prepared internal post-operation lesson learning reports, on all areas of involvement - as evidenced by the annexed list of major studies completed in the ParryEvans report. However, there is little evidence that such internal post-operation lesson 
learning reports are produced by other branches of the intelligence community. The value that such reports could provide is difficult to quantify but the changes made as a result of Franks proved their worth in 'Granby', whilst the recommendations made by the Butler Inquiry continue to be widely referenced and heralded as providing the gold standard for intelligence collection, assessment and reporting. If internal lesson reports lead to similar results as the external inquiries of Franks and Butler then the wider intelligence community may find adopting a similar practise of unending value.

\footnotetext{
${ }^{\mathrm{i}}$ The British code name for the military intervention to protect Saudi Arabia and later to dispel the Iraqis from Kuwait was Operation 'Granby'. The US called the first phase Operation 'Desert Shield' and the phase of hostilities Operation 'Desert Storm'. ii This will also reveal a fresh insight into the area of defence intelligence, for which there is currently no official history.

iii The issue of mirror-imaging was reemphasised by Butler. Butler, Review of Intelligence on WMD, p.15.

iv This lesson went too far the other way. The inquiry into the 2003 death of Baha Mousa revealed that there was poor interrogation policy, doctrine and training within the British Army. Huw Bennett, 'The Baha Mousa Tragedy'.

${ }^{v}$ Only Canada and Australia were also granted this privileged access.
} 